\title{
Classification and mapping of Spanish Mediterranean mixed forests
}

\author{
Rut Sánchez de Dios ${ }^{(1)}$, \\ Juan Carlos Velázquez ${ }^{(1)}$, \\ Helios Sainz Ollero ${ }^{(2)}$
}

\begin{abstract}
Mixed forests play an important role in promoting forest functions and services, and showed better resilience to perturbations than monospecific forests. In the Mediterranean Basin they constitute an important share of the total forest area. However, although mixed forests have been described, classified and mapped in most of the Mediterranean regions around the world, in the Mediterranean Basin they remain neglected, with direct negative consequences for forest management and conservation strategies. Our objective is to present a reliable, uniform classification along with a map of the Spanish Mediterranean Mixed Forests (MMF) as a tool for their management and conservation in Spain. The digital Spanish Forest Map was analyzed to identify MMF. The most frequent tree species combinations were identified and their representativeness in terms of the total forest area was analyzed. In addition, to ensure environmental homogeneity in the proposed classification, the arrangement of each tree species combination within the Spanish Mediterranean ecoregions was evaluated using the Pearson Chi-square test. Based on our results, Spanish MMF currently cover $27.07 \%$ of the Mediterranean natural forest area. They were divided into 9 main ecological groups and 23 subtypes. The classification of Spanish MMF and the distribution map represent a first step towards recognizing the importance of mixed forests in the vegetation of the Mediterranean Basin. Together they may provide a valuable basis to improve future forest management, monitoring and conservation strategies both at national and European level.
\end{abstract}

Keywords: Mixed Forests, Mediterranean Forests, Vegetation Classification, Forest Map, Mediterranean Mixed Forest

the Mediterranean Basin. Whilst Mediterranean mixed forests (MMF) have been described in most of the Mediterranean regions (see for example Wilcox 1996 for Chile, Barbour et al. 2007 for California and Beard et al. 2013 for NW Australia), mixed forests are scarcely represented in vegetation classifications and vegetation maps of countries in the Mediterranean Basin, even though they represent an important part of the Mediterranean forest area. For example, in the map of the Natural Vegetation of Europe (Bohn et al. 2003), Mediterranean sclerophyllous forests (group $J$ ) and xerophytic coniferous forests (group K) are described as formations dominated by a single tree species. Similarly, the for-
(1) Departamento de Biodiversidad, Ecología y Evolución. Facultad de Biología, Universidad Complutense de Madrid, C/José Antonio Novais 12, 28040, Madrid (Spain); (2) Departamento de Biología, Facultad de Ciencias, Universidad Autónoma de Madrid, C/Darwin 2, 28049 Madrid (Spain)

@ Rut Sánchez De Dios (rut.sanchez@ucm.es)

Received: Apr 16, 2018 - Accepted: Aug 01, 2019

Citation: Sánchez de Dios R, Velázquez JC, Sainz Ollero H (2019). Classification and mapping of Spanish Mediterranean mixed forests. iForest 12: 480-487. - doi: 10.3832/ifor2817-012 [online 2019-10-14]

Communicated by: Luca Salvati est classifications from EUNIS (Davies et al. 2004) or from the European Forest Types (EEA 2007) do not include all types of MMF; for example mixed forests of conifers and perennial oaks are not considered. Spanish forests account for the largest percentage of Mediterranean forests in Europe $(21 \%$ of the total forest area in Mediterranean countries - FAO 2013). In addition, Spain is considered a hot spot for forest presence in the Mediterranean basin (Noce et al. 2016). The great diversity of Spanish Mediterranean forests may be explained by different biogeographical factors. Firstly, the Iberian Peninsula was the center of origin and dispersion of several Mediterranean tree species scarcely represented elsewhere (e.g., Pinus nigra subsp. salzmanni, Quercus faginea subsp. faginea or even Q. pyrenaica, although the latter has a larger distribution area). Secondly, the geographical location of the Iberian Peninsula allows the presence of IberoAfrican tree species (e.g., Q. faginea subsp. broteroi, $Q$. canariensis, Juniperus thurifera and to a lesser degree in terms of forest area, Abies pinsapo and Tetraclinis articulata). Finally, the orography of the Spanish mountains as well as the variety of substrates favors the presence and mixture of several tree species with different ecological requirements (Costa et al. 1997). As a consequence, mixed forests cover $19 \%$ of the total Spanish forest area (MAPAMA 
2017), although there are no figures for the Mediterranean region alone.

Despite the above situation, the Spanish forests classifications scarcely recognize the presence of MMF (Ceballos 1966, Ferreras \& Arozena 1987, Costa et al. 1997). Whilst the latest Spanish forest maps (Ruiz de la Torre 1997, MAPAMA 2006) recognize 26 types of native Mediterranean monospecific forests, they only provide a simplified classification of MMF based on dominant leaf type, i.e., broadleaved mixed forests, conifer mixed forests and broadleaved-conifer mixed forests (Tab. S1 in Supplementary material).

Why MMF have traditionally been disregarded? On the one hand, it may be a direct consequence of the phytosociological approach and its hierarchic classification. This methodology, together with the community climax concept, has been widely used for vegetation classification and mapping in most of the European countries, and specifically, in the Mediterranean ones (EEA 2014). As a result, monospecific forests have long been considered as a stable component of Mediterranean Basin vegetation, while mixed forests have only been considered as intermediate/successional stages (see for example Blasi et al. 2000). Consequently, MMF are not usually present in the description, classifications and maps of the potential natural vegetation either at national (Rivas-Martínez et al. 2001, Pedrotti 1993) or continental level (Mucina et al. 2016). On the other hand, mixed forests have often been considered as local ecotones derived from temporary intermixing between monospecific forests. However, ecotones may cover extensive areas in mountain regions with reduced slope (Costa et al. 1997). Hence, mixed forests may represent a large share of the forested area. Finally, monospecific forests are always easier to work with and more "friendly" for informational tasks.

The absence of MMF in European classifications has direct negative effects on forest management and conservation strategies since an important amount of our forest ecosystems are being disregarded. The important role of Mediterranean forests in European biodiversity has to be considered as these forests contain nearly twice as many woody species as Central and Northern European forests (Quézel et al. 1999) and are also highly varied in terms of growth forms, morphology, physiology and phenology of trees (Gauquelin 2011). On the other hand, if one part of MMF biodiversity is neglected in the vegetation classifications, then it will obviously be missing in national or continental conservation policies. MMF are neglected in the European Habitat Directive with the exception of ravine forests. Indeed, we found therein only one MMF: 9320 Olea and Ceratonia forests.

As reliable, uniform classification and vegetation mapping is highly important for research, management and monitoring and since both have been recognized as fundamental tools for improving the assessment and monitoring of forest biodiversity in Europe (EEA 2007), there is currently a recognized need for MMF classification.

Our objective is to present a classification and a map of the Spanish mixed forest within the Mediterranean bioregion, which may be of particular use in forest management and biodiversity conservation strategies. Furthermore, the simple methodology presented in this study, based on readily available cartographical information, could encourage the identification, classification and mapping of MMF in other countries of the Mediterranean Basin.

\section{Material and methods}

To identify the distribution of Spanish MMF, the Spanish Forest Map scale 1:50.000 (SFM50 - MAPAMA 2006) was used. This digital map is the most complete and updated forest map at national level and is based on photo-interpretation of digital images and field work. The SFM50 map is planned to be periodically updated (approx. each 10 years), though the newest version has not been released yet. It includes 29 types of native monospecific forests and 15 types of native mixed ones; however, only monospecific forests are identified at specific level (on the basis of the dominant species - see Tab. S1 in Supplementary material). The spatial distribution of the species is organized in polygons representing homogeneous area of forest distribution. Moreover, SFM50 contains not only forests but also other structural types such as scrublands, grasslands, etc. According to FAO recommendations, only those polygons with a canopy cover fraction of more than $10 \%$ were considered as forests (FRA 2015). Thus woodlands ("dehesas") were not analyzed in this study.

The SFM50 provides information regarding the presence and proportion (occupancy) of up to three tree species in each polygon (minimum resolution for forests area $=2.5 \mathrm{ha}$ ). It also indicates whether the forest distribution within each polygon is uniform or it is a juxtaposition of different small pure stands (mosaics).

As a first step, we divided the forest areas from the SFM50 into Biogeographic regions using the European Biogeographical region limits (European Environment Agency Boundaries 2016) and those falling within the Mediterranean region were selected. Since we focused on natural forests only, all the areas subject to past reforestations were identified and removed based on the information obtained from the Spanish Information System of Forest Tree Species (GIS-FOREST 2016).

Next, mixed and monospecific forest areas were identified by taking into account the proportion of the tree species in each polygon. Out of the three tree species present in each SFM50 polygon, the most abundant was referred to as "principal tree". When the canopy cover of the princi- pal tree was greater than $70 \%$, then the polygon was considered as monospecific forest (SoEF 2003), while if the canopy cover of the principal tree was less than $70 \%$ and with a uniform distribution, then the polygon was considered as mixed forest. Riparian forests were not considered and all polygons containing non-native species were discarded. Quercus ilex L. distribution was separated into Q. ilex subsp. ilex L. and Q. ilex subsp. ballota (Desf.) Samp., according to Costa et al. (1997).

After the basic cartography of all native MMF had been prepared, we classified the selected areas into different mixed forest types based on the most frequent tree combinations and the Spanish biogeography. Using the SFM50 data set, the second and the third most abundant trees ("secondary tree" and "tertiary tree") in each polygon were also identified (see Fig. S1 in Supplementary material). For each "principal tree" species, we selected the main companion "secondary tree" species, and the main pairs for the total area of mixed forests were identified (Tab. 1). Trios were also identified, using the main third coexisting species (tertiary tree - Fig. S2 in Supplementary material).

MMF were mapped according to the above mentioned pairs and trios. First, the geographic distribution of the main pairs and trios was explored. To ensure environmental homogeneity we analyzed their arrangement within the seven Spanish Mediterranean ecoregions (Classification level 2 - Galicia-Herbada et al. 2011; see also Tab. 2 and Fig. $\mathrm{S} 3$ in Supplementary material). The Pearson's $\chi^{2}$ test $(\alpha=0.05)$ and pairwise comparisons using Bonferroni's corrections were applied using the software SPSS $^{\oplus}$ ver. 22 (IBM, Armonk, NY, USA) to identify significant differences in the presence of each mixed forest group in the seven Mediterranean Ecoregions. Pairs present in two or more contrasting ecoregions (i.e., with very different environmental conditions, particularly in terms of soil $\mathrm{pH}$ - acidic or alkaline, based on the percentage of acidic/alkaline rocks) were split into different mixed forest types (e.g., Q. ilex subsp. ballota - Q. faginea, normally found in alkaline substrates, or Q. ilex subsp. ballota - Juniperus oxycedrus in acidic ones). The percentage of acidic/alkaline rocks was obtained from the Spanish Geological Map (IGME 1995).

In a second step, different combinations of similar pairs and trios living in close proximity within the same ecoregion were merged in order to form larger groups. For example, Pinus halepensis - Q. ilex subsp. ballota pairs from the ecoregions 6 and 7 were merged with $P$. halepensis - Juniperus oxycedrus, $P$. halepensis - J. phoenicea pairs and with Q. ilex subsp. ballota - J. oxycedrus - P. halepensis, Q. ilex subsp. ballota - J. phoenicea - P. halepensis trios. High-diversity mixed forests were identified where many different pairs and trios were found in the same areas (mountain Sub-Mediter- 
Tab. 1 - Main pairs of tree species identified in MMF of Spain. Rows represent the main species within the primary tree field in the SFM50 and columns the species in the secondary tree field. Their importance in terms of percentage of area with respect to the total area of MMF is reported using the following classes: (1) >50\%; (2) between 50-25\%; (3) between $25-10 \%$; $(4)<10 \%$.

\begin{tabular}{|c|c|c|c|c|c|c|c|c|c|c|c|c|c|c|c|c|c|c|c|c|c|c|c|c|c|c|}
\hline & \multirow[b]{2}{*}{ Species } & \multicolumn{25}{|c|}{ Secondary tree } \\
\hline & & 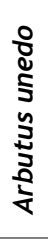 & 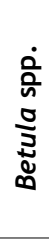 & 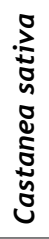 & 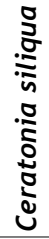 & 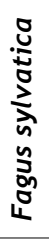 & 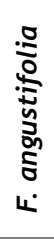 & 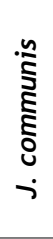 & 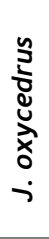 & 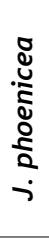 & 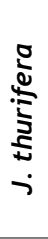 & 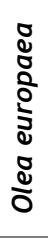 & $\begin{array}{l}\frac{n}{n} \\
\frac{n}{2} \\
\frac{0}{0} \\
\frac{0}{0}\end{array}$ & 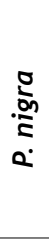 & \begin{tabular}{l}
$\grave{d}$ \\
\multirow{n}{n}{} \\
0 \\
.5 \\
0 \\
0
\end{tabular} & $\frac{0}{2}$ & 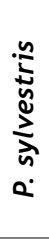 & $\begin{array}{l}\frac{n}{5} \\
\frac{0}{\delta} \\
\frac{0}{\delta} \\
\delta \\
\delta \\
\dot{\sigma}\end{array}$ & 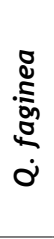 & 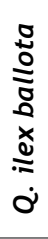 & 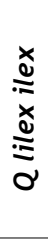 & 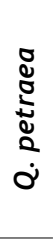 & 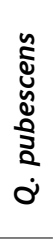 & 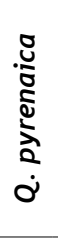 & $\begin{array}{l}\grave{\Xi} \\
\stackrel{0}{0} \\
\dot{\alpha}\end{array}$ & 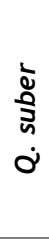 \\
\hline \multirow{6}{*}{ 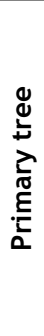 } & P. nigra & - & - & - & - & - & - & 4 & 4 & 4 & 2 & - & 2 & - & 3 & - & 2 & - & 2 & 1 & 4 & - & 4 & - & - & - \\
\hline & P. pinaster & - & - & - & - & - & - & - & 4 & 4 & 4 & - & 2 & 2 & - & 3 & 3 & - & 4 & 2 & - & - & - & 3 & - & 3 \\
\hline & P. sylvestris & - & - & - & - & 2 & - & - & - & - & 4 & - & 4 & 1 & 4 & - & - & - & 2 & 3 & 3 & 4 & 3 & 4 & - & - \\
\hline & Q. faginea & 4 & - & - & - & - & - & 4 & 4 & - & 4 & - & 4 & 3 & - & - & 3 & - & - & 1 & 4 & - & - & 4 & - & 4 \\
\hline & Q. ilex ballota & 4 & - & - & - & - & - & 4 & 2 & 4 & 3 & 4 & 3 & 3 & - & 4 & 4 & - & 1 & - & - & - & 4 & 3 & - & 2 \\
\hline & Q. pyrenaica & 4 & 3 & 2 & - & 3 & 4 & 4 & - & - & - & - & - & - & 4 & - & 4 & - & 2 & 1 & - & 4 & - & - & 3 & 4 \\
\hline
\end{tabular}

ranean and northeastern Sub-Mediterranean mixed forests). However, such classification criteria were maintained for other mixed forests where these were of sufficient importance in the area (in terms of surface) and no other similar pairs were present nearby.

Finally, as a validation approach, other biogeographical descriptions of Spanish forests (Ceballos 1966, Ferreras \& Arozena 1987, Costa et al. 1997) and European forest classifications (Davies et al. 2004, EEA 2007) were taken into account.

\section{Results}

Spanish MMF account for $23,586.35 \mathrm{~km}^{2}$ or $27.07 \%$ of the natural forest area in Spain (excluding dehesas). Q. ilex subsp. ballota is by far the most important species in the Spanish MMF. This is not surprising as it is the most widespread species in Spanish forests (MAPAMA 2017). The next in order of importance in the Spanish MMF is the Sub-Mediterranean species Q. faginea (37
\%). Pine species ( $P$. halepensis and $P$. nigra) and Juniper species (Juniperus oxycedrus and J. phoenicea) have also emerged as important components of mixed forest (Fig. 1).

According to results of the intersection between the distribution of tree pairs and trios and the Spanish Ecoregions, the MMF have been divided into 9 main ecological groups, depending on their environmental (climatic and edaphic) requirements (Fig. 2, Tab. S2 in Supplementay material). Most of the groups are present in two different Ecoregions, ensuring their ecological differentiation, except for Northeastern SubMediterranean mixed forests and Continental mixed forests, both of which are only present in Ecoregion 6, although they present different, non-overlapping distribution areas within that Ecoregion (Fig. 2, Tab. 3). Furthermore, the differences between the species composition in both groups also support their ecological distinction. Sub-Mediterranean mixed forests are the most widespread in Spain, though this type of forest is particularly prevalent in the Northeast (Ecoregions 6, 7 and 9).

Overall, $46.45 \%$ of the mixed forests are located in the Mediterranean-Eurosiberian climatic transition zones (Sub-Mediterranean and Sub-Atlantic mixed forests, groups 1 to 3 - Tab. S2 in Supplementary material), according to Sánchez de Dios et al. (2009). Each main group has been divided into different subtypes depending on species composition. These subtypes are therefore ecologically related and share one or more species (Tab. S2, Figs. S4-S8 in Supplementary material).

Sub-Atlantic mixed forests are mainly distributed in northwestern Spain on acidic soils (Ecoregions 2, 5 and 4 - Fig. 2). The main species in these forests is the marcescent oak Quercus pyrenaica Willd. of which six subtypes were identified. All of these areas comprise broadleaved species except for the oak-pine mixed forests of the Central range, Sierra Morena and Sierra

Tab. 2 - Environmental descriptors of Spanish Ecoregions to classification level 2 (from Galicia-Herbada et al. 2011). (C): Continentality (Goreziski index); (P/ETP): Aridity (Annual rainfall/Potential Evotranspiration); (P): Annual rainfall; (PS): Summer rainfall; (T): Annual mean temperature; (TM): Temperature of the warmest month; (Tm): Temperature of the coldest month; (AR): Percentage of acidic rocks; (AKR): Percentage of alkaline rocks; (SC): Evaporitic or calcareous sediments; (SS): Siliceous sediments; (Alt): Altitude; (Belt): Crosswalk with bioclimatic belts (http://www.globalbioclimatics.org/form/tb_med.htm).

\begin{tabular}{|c|c|c|c|c|c|c|c|c|c|c|c|c|c|c|}
\hline Ecoregion & $\begin{array}{l}\text { Biog. } \\
\text { Reg. }\end{array}$ & Belt & $\cup$ & $\frac{\text { 岀 }}{\stackrel{\alpha}{a}}$ & $\begin{array}{l}\widehat{\underline{\varepsilon}} \\
\underline{\xi} \\
0\end{array}$ & $\begin{array}{l}\widehat{E} \\
\text { E⿱ } \\
\check{\Sigma}\end{array}$ & $\underset{1}{0}$ & $\stackrel{0}{0}_{\substack{0 \\
1}}$ & 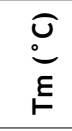 & $\begin{array}{l}\stackrel{\varrho}{\stackrel{\alpha}{<}} \\
\text { }\end{array}$ & 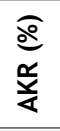 & $\underset{\text { ¿ }}{\stackrel{Ð}{9}}$ & $\begin{array}{l}Ð \\
\approx\end{array}$ & 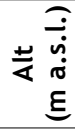 \\
\hline 1 & Atl & - & 8.1 & 2.28 & 1876 & 186 & 13.1 & 19.1 & 7.7 & 1 & 95 & 0 & 3 & 308 \\
\hline 2 & Atl & - & 11.6 & 7.71 & 1342 & 155 & 11.5 & 18.3 & 5.6 & 15 & 78 & 2 & 4 & 572 \\
\hline 3 & Med & Thermomed & 24.7 & 0.42 & 532 & 32 & 16.7 & 25.5 & 9.2 & 20 & 24 & 46 & 9 & 324 \\
\hline 4 & Med & Mesomed-Supramed & 29.1 & 0.55 & 592 & 62 & 13.7 & 13.9 & 5.2 & 0 & 79 & 0 & 21 & 728 \\
\hline 5 & Atl & Supra-submed & 17.6 & 1.40 & 1175 & 166 & 8.7 & 16.9 & 1.8 & 29 & 63 & 8 & 1 & 1189 \\
\hline 6 & Med & Supramed & 22.4 & 0.75 & 677 & 131 & 11.4 & 20.5 & 3.6 & 47 & 3 & 47 & 3 & 830 \\
\hline 7 & Med & Mesomed & 29.6 & 0.40 & 451 & 63 & 13.9 & 24.2 & 5.4 & 34 & 0 & 56 & 10 & 708 \\
\hline 8 & Med & Termomed & 18.4 & 0.71 & 918 & 2517 & 16.4 & 24.1 & 10.5 & 57 & 20 & 19 & 0 & 296 \\
\hline 9 & Alp & - & 22.6 & 1.19 & 1023 & 228 & 9.0 & 18.8 & 1.5 & 34 & 52 & 12 & 2 & 1246 \\
\hline
\end{tabular}



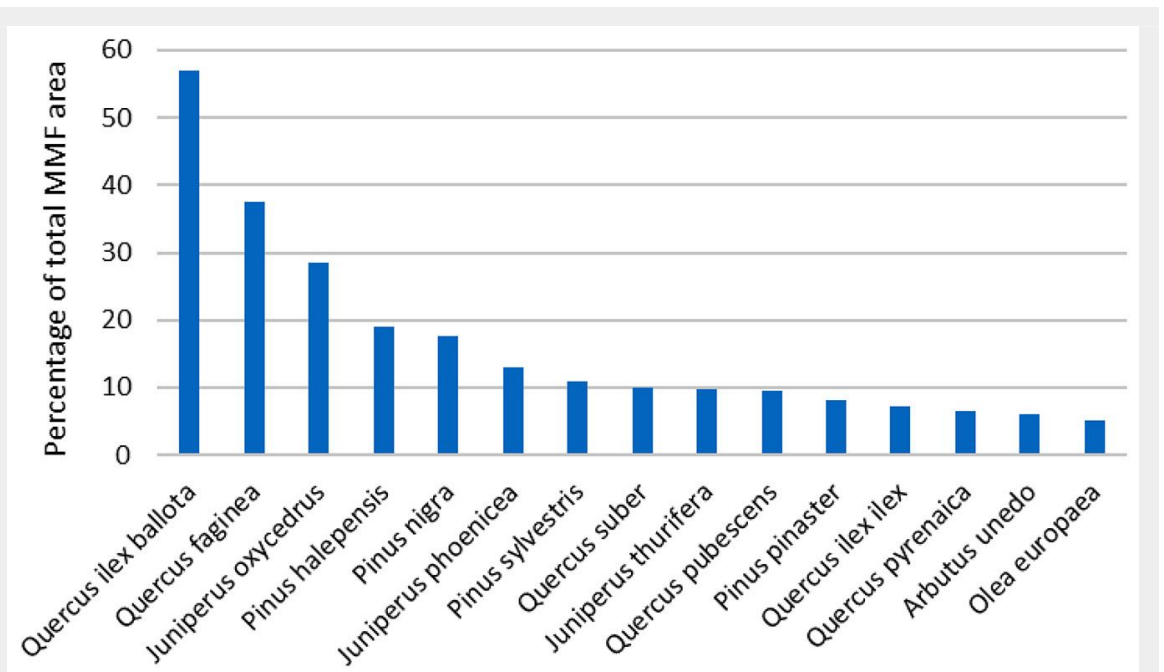

Fig. 1 - Main species coexisting in MMF.

Nevada mountains with the conifers Pinus sylvestris L. and P. pinaster Aiton (Fig. S4). Typically, Atlantic species such as Q. robur L., F. sylvatica L., Q. petraea (Matt.) Liebl or Castanea sativa Mill. can be found together with Sub-Mediterranean species (Q. pyrenaica) or even Mediterranean species ( $Q$. ilex subsp. ballota, Q. suber L.). Oak-ash forests were included due to their singularity (Costa et al. 1997), though they only cover a small area and therefore were not highlighted as a main pair (Tab. 1)

Sub-Mediterranean mixed forests are found in the northeast of Spain on alkaline soils, mainly in the Pyrenean Mountains but also in the Iberian Range and the Betic Mountains (Fig. S5). In this area, another marcescent oak, Q. faginea subsp. faginea replaces $Q$. pyrenaica as the main species.
Mountain conifers such as $P$. sylvestris, $P$. nigra J.F. Arnold subsp. salzmannii (Dunal) Franco and Juniperus thurifera L. and/or typically Mediterranean ones (J. oxycedrus, J. phoenicea, P. halepensis) are mixed with Atlantic, Sub-Mediterranean or Mediterranean broadleaved species (F. sylvatica, Q. faginea, Q. pubescens Willd. and Q. ilex

Northeastern Sub-Mediterranean mixed forests (Fig. 2, Fig. S5, Fig. S6) have been differentiated based on their high diversity and uniqueness. The mixture of conifer and broadleaved species from both Atlantic and Mediterranean biomes is maximum, together with new taxa such as Q. ilex subsp. ilex.

Continental mixed forests are located on the plateaus of the Iberian Range on alkasubsp. ballota). line soils (Fig. S6 in Supplementary material). Iberian Juniper (Juniperus thurifera) is the main species. Two groups have been described based on the presence/absence of Q. ilex subsp. ballota

Five typically Mediterranean groups of mixed forests were identified: one Western Mediterranean on acidic soils; two Eastern Mediterranean on alkaline soils (one located in mountain areas and the other in lowlands); and two thermophilic groups, according to local rainfall (Tab. 2). While Q. ilex subsp. ballota is the main species in both the Eastern and Western groups, it is not found in the thermophilic mixed forests.

Eastern montane mixed forests are mainly composed of Q. ilex subsp. ballota and the Mediterranean mountain conifer $P$. nigra subsp. salzmanni. However, another interesting type of mixed forest composed exclusively of pine species ( $P$. nigra subsp. salzmannii, $P$. halepensis and $P$. pinaster) is distributed throughout the Iberian Range and the Baetic Mountains (Fig. S6 in Supplementary material).

The two types of lowland Eastern Mediterranean mixed forests are closely related. The main difference between them is the presence/absence of $P$. halepensis (Tab. 1, Fig. S6).

Apart from the presence of Q. ilex, Western Mediterranean mixed forests are also characterized by the presence of $Q$. suber. This group of forests includes two mixed oak forest types, one of which is of particular interest as all the four species present are oaks (Quercus ilex subsp. ballota, Q. faginea subsp. broteroi, Q. suber and Q. pyrenaica). Morevoer, we found also two pine-oak mixed forests with either Q. ilex or $Q$. suber and $P$. pinaster as well as $P$.

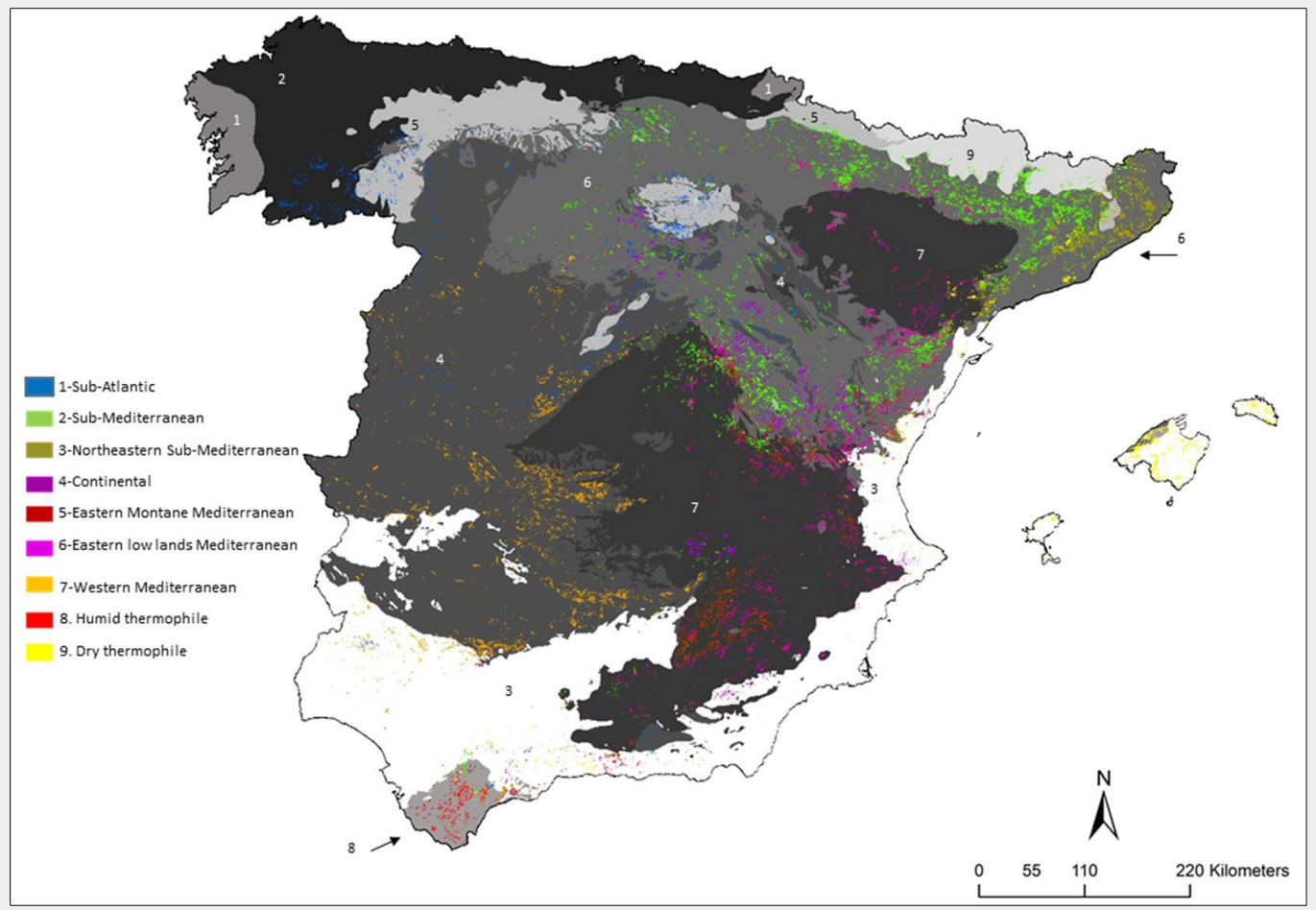

Fig. 2 - Distribution of Spanish Mediterranean mixed forests (MMF). Numbers and grey shades represent the distribution of Spanish Mediterranean Ecoregions (GaliciaHerbada et al. 2011). See Tab. 2 for environmental descriptors of the Ecoregions and Tab. S2 (Supplementary material) for the description of the Spanish MMF. 
Tab. 3 - Results of the Pearson's $\chi^{2}$ test (significance level $=0.05$ ) and pair comparisons using Bonferroni's corrections. For each significant pair, the key for the category with the smallest column proportion appears under the category with the largest column pro portion. (a): This category was not used in the comparisons because its column proportion is equal to zero or one.

\begin{tabular}{|c|c|c|c|c|c|c|c|c|c|}
\hline \multirow{3}{*}{ Ecoregion } & \multicolumn{9}{|c|}{ Mediterranean Mixed Forests } \\
\hline & 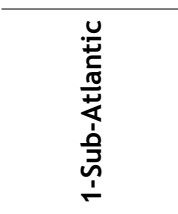 & 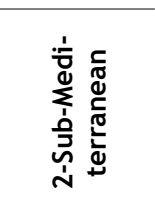 & 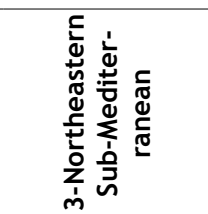 & 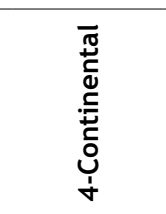 & 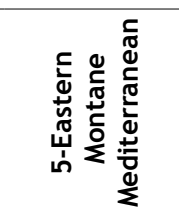 & 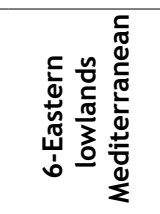 & 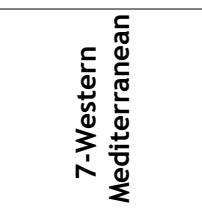 & 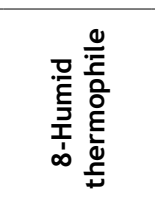 & 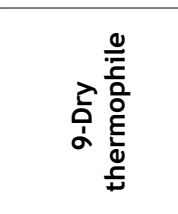 \\
\hline & (A) & (B) & (C) & (D) & (E) & $(F)$ & $(G)$ & (H) & (I) \\
\hline 2 & B C F G & - & - & -(a) & -(a) & - & - & - (a) & -(a) \\
\hline 3 & B C & $\mathrm{C}$ & - &.$^{(a)}$ & $A B C$ & $A B C E H$ & $A B C E$ & $A B C$ & ABCEFGH \\
\hline 4 & B C DEFH I & $\mathrm{FHI}$ & $\mathrm{HI}$ & B CEFH I & $\mathrm{HI}$ & $\mathrm{HI}$ & ABCDEFHI & - & - \\
\hline 5 & BCDEFI & DEFI & B DEFI & $\mathrm{F}$ & - & - & -(a) & (a) & - \\
\hline 6 & G H & AEFGH I & A B DEFGH I & AEFGH I & A G H I & AE G H I & $\mathrm{H}$ & - & G H \\
\hline 7 & - & ACG & $\mathrm{A}$ & AC G & $A B C D F G I$ & $A B C D G I$ & $A C$ & -(a) & $A C G$ \\
\hline 8 & $\mathrm{~F}$ & - & -(a) & -(a) & - & - & $A B E F$ & ABEFGI & $A B E F G$ \\
\hline 9 & - & $A F$ & $A F$ & -(a) & -(a) & - & -(a) & $-^{\text {(a) }}$ & $-^{(a)}$ \\
\hline
\end{tabular}

pinea and one Juniper-oak mixed forest (Quercus ilex subsp. ballota, Juniperus oxycedrus - Fig. S7 in Supplementary material).

Q. suber, Olea europaea L. and Pinus halepensis are the main species present in thermophilic mixed forests; Q. suber in the more humid forests and $P$. halepensis in the drier ones (Fig. S8 in Supplementary material).

\section{Discussion}

Mediterranean mixed forests in Spain

Mixed forests represent more than a quarter of the natural Mediterranean forest area in Spain. Nonetheless, as far as we know, this is the first attempt aimed at estimating mixed forest area in the Mediterranean Spain. The result of this study highlights the importance of MMF in the Mediterranean and the need for classification and mapping of this vegetation. In a European context, Spanish Mediterranean forests show a great diversity and uniqueness of trees (Costa et al. 1997), which is also reflected in the Spanish MMF. The contact between different climatic regions, the mountainous orography and the variety of substrates could have favored the presence of different types of mixed forests.

Climatic transition zones (Sub-Mediterranean and Sub-Atlantic) are confirmed as areas of high tree diversity and of interest for forest conservation (Sánchez de Dios et al. 2009, Hernández et al. 2017). According to Bohn et al. (2003), broadleaved mixed forests ("thermophilous mixed deciduous broadleaved forests") are the natural, potential vegetation of these areas. However, in Spain these forests also include perennial broadleaved species (Q. ilex subsp. ballota and Q. suber) and conifers (both pine and juniper species), increasing their species diversity and singularity. Surprisingly, these forests have not been previously described or mapped in Spain, either at re- gional or national level (Rivas-Martínez 1987, Ruiz de la Torre 1997).

Pine-oak mixed forests, in their different combinations, account for a large proportion of MMF in Spain. Among all the pineoak forests, the $P$. halepensis - Q. ilex subsp. ballota forest type is the most important in terms of area. This is in agreement with the rest of the Mediterranean Basin, where the presence of Aleppo pine ( $P$. halepensis) and holm oak ( $Q$. ilex) mixed forests is also significant (for a review see Scheffer 2012). Moreover, pine-oak forests in Spain also include juniper species, mainly $J$. oxycedrus and $J$. phoenicea. Indeed, juniper species (J. thuripera, J. phoenica and J. oxycedrus) have been identified as important components of MMF in Spain, both in mixed conifer forests ( $P$. sylvestris, $P$. nigra subsp. salzmannii and $J$. thurifera mixed forest) and in oak-juniper forests ( $Q$. ilex subsp. ballota - J. thurifera; Q. faginea, Q. ilex subsp. ballota and J. thurifera; Q. ilex subsp. ballota - J. oxycedrus mixed forests) as well as in pine-oak mixed forests (Q. ilex subsp. ballota, J. oxycedrus, $J$, phoenicea and $P$. halepensis). Coniferous mixed forests, either exclusively composed of pine species or by a mixture of pines and junipers, are therefore an important part of the Spanish forest landscape, though they are often described or mapped as monospecific forest types. Despite the fact that pine-juniper mixed forests are a recognized mixed forest type in other Mediterranean regions (e.g., the Pinyon-juniper forest type in California), they have not been described yet in Spain. Junipers are usually mentioned as companions of monospecific oak or pine forests (e.g., in the associations Junipero oxycedri - Quercetum rotundifoliae RivasMartinez 1966, Junipero phoeniceae - Pinetum clusianae F. Valle, Mota and GómezMercado, 1989 - Rivas-Martínez et al. 2001).

As for broadleaved mixed forests, perennial and deciduous (marcescent) oaks in- clude four different subtypes of mixed forests (Q. faginea - Q.ilex subsp. ballota; Q. pyrenaica - Q. ilex subsp. ballota; Q. canariensis - Q. suber; Q.ilex subsp. ballota - Q. suber - Q. faginea - Q. pyrenaica). The co-occurrence of evergreen and deciduous species is quite common in the Mediterranean biome (Di Paola et al. 2017). Although evergreen oaks are better adapted to the Mediterranean climate, being less vulnerable to drought than deciduous oaks, many examples of the co-occurrence of oaks with different leaf traits in the Mediterranenan Basin have been reported (Damesin et al. 1998). Wherever an intermediate range of soil water content occurs, the different groups attain a stable coexistence equilibrium (Di Paola et al. 2017). Land use may also affect the coexistence of evergreen and deciduous oak species. For example, Urbieta et al. (2008) reported an increase in the density of evergreen cork oaks and a decrease of marcescent $Q$. canariensis over the last century as result of historical forest management in Spain.

Although mixed oak forests have been previously described in the literature for Spain (e.g., Q. suber - Q. canariensis), other mixed types have never been considered. This is the case of the Portuguese and Holm oak forest type (Q. faginea-Q. ilex subsp. ballota) as these comprise the second mixed forest subtype in area. Interestingly, these forest types were described in the first Spanish phytosociological classifications as climax stages (Rivas Goday \& Bellot 1942), but then neglected in later classifications. Hence, in the revision of the Iberian Quercetea ilicis class, monospecific forests of both species should be classified as two different phytosociological classes: Quercetea ilicis and Querco fagetea (RivasMartínez 1974). The strict distinction between the phytosociological classes including Mediterranean conifer forests (Pino-Juniperetea), Mediterranean perennial oak forests (Quercetea ilicis) and Mediterra- 
nean deciduous (marcescents) oak forest (Querco-Fagetea) leaves little room for the description of Mediterranean mixed forests, i.e., pine-oaks or perennial-marcescent oak forests.

\section{Mixed forests and vegetation dynamics}

Our results highlight the importance and great diversity of MMF in the studied area. However, the question of whether the mixed forests reported in this study are stable vegetation stages or will evolve towards monospecific formations remains unanswered. For example, forest recovery following the abandonment of agricultural and silvicultural land use may led to the growth of mixed forests (Scheffer 2012, Hernández et al. 2017). In particular, regarding Continental Mixed Forests (group 4 - Fig. 2, Tab. S2 in Supplementary material), DeSoto et al. (2010) reported that monospecific lowland forests of J. thurifera in Spain were colonized by $P$. sylvestris and $Q$. ilex subsp. ballota after land use changes. Similarly, as regards the 5 types of pine-oak mixed forests proposed (1.4 Oak-pine Sub-Atlantic mixed forests; 5.2 Holm oak-Austrian pine mixed forests; 6.2 Holm oak juniper and Aleppo pine mixed forests; 7.4 Cork oak and pines mixed forest; 7.5 Holm oak and pines mixed forests), the long history of Spanish reforestations should be taken into account. Most reforestations during the second half of the $20^{\text {th }}$ century in Spain led to monospecific forests composed of Pinus species (Valdell et al. 2016). The decrease in silvicultural interventions through time together with the reduction in livestock grazing is now leading to a progressive process of colonization by other tree species, mainly Quercus (Vayreda et al. 2016, Martín-Alcón et al. 2015). Consequently, the 5 types of pine-oak mixed forests described in this study might also be interpreted as transitional stages leading to oak dominated forests.

Nonetheless, there are also strong evidences pointing to the stability and persistence of mixed forests. Both palynological (Morales-Molino et al. 2017) and modelling studies (Zavala \& Bravo De la Parra 2005) at landscape level revealed that pine species are able to persist. In addition, palaeoecological records also point to the past coexistence of different tree species in mixed forests in many areas of Mediterranean Spain (Carrión et al. 2000). At the same time, human use has been reported to led to a reduction in the extent as well as the structural and compositional diversity of forests in the Mediterranean Basin in general (Blondel 2006) and in Spain in particular (Valbuena-Carabaña et al. 2010). Finally, recent research showed that mixed forests are more resilient to perturbations than monospecific forests (De Dios-García et al. 2015). Indeed, the Spanish MMF may represent stable, resilient stages of the community dynamic. In that case, ecological succession may lead towards mixed rather than monospecific forests.

Conclusions and implications for forest conservation and management in the Mediterranean Basin

To date, the area occupied by MMF in Spain has not been quantified, classified or mapped. This has direct negative consequences for forest management and conservation strategies since a relevant part of Spanish forest ecosystems are being disregarded. According to our results, $27 \%$ of the Spanish Mediterranean natural forest area (excluding dehesas and ravine forests) corresponds to mixed forests. Therefore, the classification and map presented in this study may help highlighting the importance of mixed forests in Mediterranean Basin vegetation and provide a first step towards their inclusion in management and conservation policies.

The methodology presented in this study, based on the SFM50 and the use of Ecoregions may be easily adapted to other types of forest data (e.g., forest inventories or remote sensing datasets) or bioclimatic classifications (Metzger et al. 2013).

Finally, the map obtained in this study provides a picture of the current distribution of Spanish Mediterranean natural mixed forest in the decade 1995-2005, and a basis for future monitoring of the effect of global change on the dynamic of forests communities. A digital version of the map is available at Mendeley data repository (Sánchez De Dios et al. 2019)

\section{List of abbreviations}

- MMF: Mediterranean Mixed Forests;

- SFM50: Spanish Forest Map at the scale 1:50.000.

\section{Acknowledgements}

The authors thank Laura Hernandez for her valuable comments on the manuscript.

\section{Funding}

This work has been supported by the Spanish Ministry of Environment (MAPA$M A$ ) in the framework of the project "National System for Monitoring and Conservation of Spanish Habitats" through TRAGSATEC as instrumental agency.

\section{Nomenclature}

Amaral Franco (1990), except for Quercus pubescens, which follows that of Govaerts \& Avishai (2000).

\section{References}

Barbour M, Keeler-Wolf T, Schoenherr AA (2007). Terrestrial vegetation of California ( $3^{\text {rd }}$ edn). University of California Press, California, USA, pp. 730. [online] URL: http://books.goo gle.com/books?id=YNAWPSMm2CUC

Beard JS, Beeston GR, Harvey JM, Hopkins AJM, Shepherd DP (2013). The vegetation of Western Australia at the 1:3.000.000 scale. Explanatory memoir $\left(2^{\text {nd }}\right.$ edn). Conservation Science Western Australia 9 (1): 1-152.

Blasi C, Carranza ML, Frondoni R, Rosati L
(2000). Ecosystem classification and mapping: a proposal for Italian Landscapes. Applied Vegetation Science 2: 233-242. - doi: 10.2307/1479 002

Blondel J (2006). The "design" of Mediterranean landscapes: a millennial story of humans and ecological systems during the historic period. Human Ecology 34: 713-729. - doi: 10.1007/s107 45-006-9030-4

Bohn U, Neuhäusl R, Gollub G, Hettwer C, Neuhäuslová Z, Raus T, Schlüter H, Weber H (2003). Map of the natural vegetation of Europe. Scale 1:2.500.000. BfN-Schriftenvertrieb, Landwirtschaftsverlag, Münster, Germany.

Bravo-Oviedo A, Pretzsch H, Ammer C, Andenmatten E, Barbati A, Barreiro S, Brang P, Bravo F, Coll L, Corona P, Den Oude J, Ducey MJ, For rester DI, Giergiczny M, Jacobsen JB, Lesinski J, Löf $M$, Mason $B$, Matovic $B$, Metslaid $M$, Morneau F, Motiejunaite J, O'Reilly C, Pach M, Ponette Q, Del Río M, Short I, Skovsgaard JP, Soliño $M$, Spathelf $P$, Sterba $H$, Stojanovic $D$, Strelcova K, Svoboda M, Verheyen K, Von Lüpke N, Zlatanov T (2014). European mixed forests: definition and research perspectives. Forest Systems 23 (3): 518-533. - doi: 10.5424/ fs/2014233-06256

Carrión JS, Parra I, Navarro C, Munueras M (2000). Past distribution and ecology of the cork oak (Quercus suber) in the Iberian Peninsula: a pollen-analytical approach. Diversity and Distributions 6: 29-44. - doi: 10.1046/j.1472-4642. 2000.00070.x

Ceballos L (1966). Mapa forestal de España, escala 1:400.000 [Forest map of Spain, scale 1:400.000]. Ministerio de Agricultura. Madrid. [in Spanish]

Coll L, Ameztegui A, Colletd C, Löfe M, Mason B, Pach M, Verheyen K, Abrudan I, Barbati A, Barreiro S, Bielakl K, Bravo-Oviedo A, Ferrari B, Govedar Z, Kulhavy J, Lazdina D, Metslaid M, Mohren F, Pereira M, Peric S, Rasztovits E, Short I, Spathelf P, Sterba H, Stojanovic D, Valstaa L, Zlatanova T, Ponettea Q (2017). Knowledge gaps about mixed forests: what do European forest managers want to know and what answers can science provide? Forest Ecology and Management 407: 106-115. - doi: 10.1016/j. foreco.2017.10.055

Costa M, Morla C, Sainz Ollero H (1997). Los bosques ibéricos. Una interpretación geobotánica [Iberian forests. A geobotanical interpretation]. Planeta, Madrid, Spain, pp. 597. [in Spanish]

Damesin C, Rambal S, Joffre R (1998). Co-occurrence of trees with different leaf habit: a functional approach on Mediterranean oaks. Acta Oecologica 19 (3): 195-204. - doi: 10.1016/S1146609X(98)80024-6

Davies CE, Moss D, Hill MO (2004). EUNIS habitat classification revised 2004. European Environment Agency, European Topic Centre on Nature Protection and Biodiversity, Copenhagen, Denmark, pp. 307. [online] URL: http://www. eea.europa.eu/themes/biodiversity/eunis/eunishabitat-classification

De Dios-García J, Pardos M, Calama R (2015). Interannual variability in competitive effects in mixed and monospecific forests of Mediterranean stone pine. Forest Ecology and Management 358: 230-239. - doi: 10.1016/j.foreco.2015. 
09.014

Del Río M, Pretzsch H, Alberdi I, Bielak K, Bravo F, Brunner A, Condés A, Ducey MJ, Fonseca T, Von Lüpke N, Pach M, Peric S, Perot T, Souidi Z, Spathelf $P$, Sterba $H$, Tijardovic $M$, Tomé $M$, Vallet $P$, Bravo-Oviedo A (2016). Characterization of the structure, dynamics, and productivity of mixed-species stands: review and perspectives. European Journal of Forest Research 135 (1): 23-49. - doi: 10.1007/s10342-015-0927-6

DeSoto L, Olano JM, Rozas V, De la Cruz M (2010). Release of Juniperus thurifera woodlands from herbivore-mediated arrested succession in Spain. Applied Vegetation Science 13: 15-25. - doi: 10.1111/j.1654-109X.2009.01045.x

Di Paola A, Paquette A, Trabucco A, Mereu S, Valentini R, Paparella F (2017). Coexistence trend contingent to Mediterranean oaks with different leaf habits. Ecology and Evolution 7: 3006-3015. - doi: 10.1002/ece3.2840

EEA (2007). European forest types. Categories and types for sustainable forest management reporting and policy ( $2^{\text {nd }}$ edn). EEA Technical Report no. 9/2006, European Environment Agency, Copenhagen, Denmark, pp. 111. [online] URL: http://www.eea.europa.eu/publica tions/technical_report_2006_9

EEA (2014). Terrestrial habitat mapping in Europe: an overview. European Environment Agency, Copenhagen, Denmark, pp. 152. - doi: 10.2800/11055

European Environment Agency Boundaries (2016). European biogeographic map. DG Environment, European Environment Agency, Brussels, Belgium. [online] URL: http://www. eea.europa.eu/data-and-maps/data/biogeogra phical-regions-europe-3

FAO (2013). State of Mediterranean forests. FAO, Rome, Italy, pp. 173. [online] URL: http:// www.fao.org/docrep/017/i3226e/i3226e.pdf

Ferreras C, Arozena ME (1987). Guía física de España: 2 - Los Bosques [Physique guide of Spain: 2 - Forests]. Alianza Editorial, Madrid, Spain, pp. 394. [in Spanish]

FRA (2015). Forest resources assessment. Working Paper 180, Terms and definitions, FAO, Rome, Italy, pp. 31. [online] URL: http://www. fao.org/docrep/017/ap862e/ap862eoo.pdf

Galicia-Herbada D, Hervás González J, Martínez Torres R, Seoane Pinilla J, Hidalgo Martín R (2011). An environmental land classification of Spain. Fitosociologia 48 (2): 101-110.

Gauquelin T (2011). Specificity and universality of forestall Mediterranean ecosystems. In: "Mediterranean Ecosystems" (Williams GS ed). Nova Science Publishers, New York, USA, pp. 1-5.

GIS-FOREST (2016). Information system of forest tree species. INIA-CIFOR, Madrid, Spain, web site. [online] URL: http://sites.google.com/site/ sigtreeforestspeciesenglis/

Hernández L, Sánchez De Dios R, Montes F, Sainz-Ollero H, Cañellas I (2017). Exploring range shifts of contrasting tree species across a bioclimatic transition zone. European Journal of Forest Research 136 (3): 481-492. - doi: 10.100 7/s10342-017-1047-2

IGME (1995). Mapa geológico de España. 1:1.000.000 [Geological map of Spain 1:1.000.000]. Web site. [in Spanish] [online] URL: http://info.igme.es/cartografiadigital/geo logica/Geologicos1MMapa.aspx?Id=Geologico1
000_(1994)

MAPAMA (2006). Mapa forestal de España 1: 50.000 [Spanish forest map 1:50.000]. Ministerio de Agricultura, Alimentación y Medio Ambiente, Área Inventario y Estadística Forestal, Madrid, Spain. [in Spanish] [online] URL: http:// www.mapama.gob.es/es/biodiversidad/servicio s/banco-datos-naturaleza/informacion-disponi ble/mfe50.aspx

MAPAMA (2017). Anuario de estadística forestal 2013 [Annual forest statistics 2013]. Ministerio de Agricultura, Pesca, Alimentación y Medio Ambiente, Madrid, Spain, pp. 117. [in Spanish] [online] URL: http://www.mapama.gob.es/es/ desarrollo-rural/estadisticas/anuario2013definiti vo_tcm7-407696.pdf

Martín-Alcón S, Coll L, Salekin S (2015). Standlevel drivers of tree-species diversification in Mediterranean pine forests after abandonment of traditional practices. Forest Ecology and Management 353: 107-117. - doi: 10.1016/j.fore co.2015.05.022

Metzger MJ, Bunce RGH, Jongman RHG, Sayre R, Trabucco A, Zomer R (2013). A high-resolution bioclimate map of the world: a unifying framework for global biodiversity research and monitoring. Global Ecology and Biogeography 22: 630-638. - doi: 10.1111/geb.12022

Morales-Molino C, Colombaroli D, Valbuena-Carabaña M, Tinner W, Salomón RL, Carrión JS, Gil $L$ (2017). Land-use history as a major driver for long-term forest dynamics in the Sierra de Guadarrama National Park (central Spain) during the last millennia: implications for forest conservation and management. Global and Planetary Change 152: 64-75. - doi: 10.1016/j.glo placha.2017.02.012

Mucina L, Bültmann H, Dierssen K, Theurillat JP, Raus T, Carni A, Sumberová K, Willner W, Dengler J, Gavilán García R, Chytry M, Hájek M, Di Pietro R, lakushenko D, Pallas J, Daniëls FJA, Bergmeier E, Santos Guerra A, Ermakov N, Valachovič M, Schaminée JHJ, Lysenko T, Didukh YP, Pignatti S, Rodwell JS, Capelo J, Weber HE, Solomeshch A, Dimopoulos P, Aguiar C, Hennekens SM, Tichy L (2016). Vegetation of Europe: hierarchical floristic classification system of vascular plant, bryophyte, lichen, and algal communities. Applied Vegetation Science 19 (1): 3-264. - doi: 10.1111/avsc.12257

Noce S, Collalti A, Valentini R, Santini M (2016). Hot spot maps of forest presence in the Mediterranean basin. iForest - Biogeosciences and Forestry 9 (5): 766-774. - doi: 10.3832/ifor1802oog

Pedrotti F (1993). Carta della vegetazione naturale potenziale d'Italia (Scala 1:1.500.000) [Map of the natural potential vegetation of Italy (scale 1:1.500.000)]. Ministero dell'Ambiente, Roma, Italy. [in Italian]

Quézel F, Médail R, Loisel Barbero M (1999). Biodiversity and conservation of forest species in the Mediterranean basin. Unasylva 50 (197): 2128. [online] URL: http://hdl.handle.net/10535/ 9505

Rivas Goday S, Bellot F (1942). Acerca de las regiones naturales de la provincia de Madrid [Regarding natural regions of Madrid province]. Revista de la Universidad de Madrid (Farmacia) 2 (5): 57-58. [in Spanish]

Rivas-Martínez S (1974). La vegetación de la clase Quercetea ilicis en España y Portugal [Vegetation of the class Quercetea ilicis in Spain and Portugal]. Anales del Instituto Botánico Cavanilles 31: 205-259. [in Spanish]

Rivas-Martínez S (1987). Memoria del mapa de series de vegetación de España 1:400.000 [Memory of the potential vegetation map of Spain 1:400.000]. ICONA, Ministerio de Agricultura, Pesca y Alimentación, Madrid, pp. 268. [in Spanish] [online] URL: http://www.magrama. gob.es/es/biodiversidad/servicios/banco-datosnaturaleza/informacion-disponible/memoria mapa_series_veg.aspx

Rivas-Martínez S, Fernández-González F, Loidi J, Lousã M, Penas A (2001). Syntaxonomical checklist of vascular plants communities of Spain and Portugal to association level. Itinera Geobotanica 14: 5-341.

Ruiz de la Torre R (1997). Mapa Forestal de España. Escala 1:200.000 [Spanish Forest Map 1:200.000]. Ministerio de Medio Ambiente, Madrid, Spain. [in Spanish]

Sánchez de Dios R, Benito Garzón M, Sainz Ollero H (2009). Present and future extensions of the Iberian Submediterranean territories as determined from the distribution of marcescent oaks. Plant Ecology 204: 189-205. - doi: 10.1007/s11258-009-9584-5

Sánchez de Dios R, Velázquez JC, Sainz Ollero H (2019). Data for: Classification and mapping of Spanish Mediterranean mixed forest. Mendeley Data, v1. [online] URL: http://data.mendeley. com/datasets/w29wz75jzf/draft?a=02752977-fa 12-40ba-a980-007eed4076a1

Scheffer E (2012). A review of the development of Mediterranean pine-oak ecosystems after land abandonment and afforestation: are they novel ecosystems? Annals of Forest Science 69: 429-443. - doi: 10.1007/s13595-011-0181-0

SoEF (2003). State of Europe's Forests 2003. The MCPFE Report on Sustainable Forest Management in Europe. Ministerial Conference on the Protection of Forests in Europe. Liaison Unit Vienna, Austria, pp. 115. [online] URL: http:// www.foresteurope.org/documentos/forests_2 003.pdf

Urbieta IR, Zavala MA, Marañón T (2008). Human and non-human determinants of forest composition in southern Spain: evidence of shifts towards cork oak dominance as a result of management over the past century. Journal of Biogeography 35: 1688-1700. - doi: 10.1111/j.13 65-2699.2008.01914.x

Valbuena-Carabaña M, De Heredia UL, FuentesUtrilla P, González-Doncel I, Gil L (2010). Historical and recent changes in the Spanish forests: $a$ socio-economic process. Review of Palaeobotany and Palynology 162 (3): 492-506. - doi: 10.1016/j.revpalbo.2009.11.003

Valdell E, De Miguel S, Pemán J (2016). Largescale reforestation and afforestation policy in Spain: a historical review of its underlying ecological, socioeconomic and political dynamics. Land Use Policy 55: 37-48. - doi: 10.1016/j.land usepol.2016.03.017

Vayreda J, Martinez-Vilalta J, Gracia M, Canadell JG, Retana J (2016). Anthropogenic-driven rapid shifts in tree distribution lead to increased dominance of broadleaf species. Global Change Biology 22 (12): 3984-3995. - doi: 10.1111/gcb. 13394 
Wilcox K (1996). Chile's native forests. A conservation legacy. Ancient Forest International (AFI), NW Wild Books, Redway, CA, USA, pp. 148.

Zavala MA, Bravo De la Parra R (2005). A mechanistic model of tree competition and facilitation for Mediterranean forests: scaling from leaf physiology to stand dynamics. Ecological Modelling 188: 76-92. - doi: 10.1016/j.ecolmod el.2005.05.006

\section{Supplementary Material}

Tab. S1 - Classification of native forests in the Spanish Forest Map 1:50.000.

Tab. S2 - Classification of the mixed forest types proposed for Mediterranean Spain.
Fig S1 - Percentage of total area of the main tree species coexisting in mixed forests.

Fig. S2 - Main trios identified.

Fig. S3 - Geographical distribution of Spanish Ecoregions to level 2 (Galicia-Herbada et al. 2011, 2014).

Fig. S4 - Distribution of the Sub-Atlantic subtypes of Mediterranean mixed forests.

Fig. S5 - Distribution of Sub-Mediterranean subtypes of Mediterranean mixed forests and of the Northeastern Sub-Mediterranean type.
Fig. S6 - Distribution of the Continental, Eastern Montane Mediterranean and Eastern lowland Mediterranean subtypes of Mediterranean mixed forests and of the Northeastern Sub-Mediterranean type.

Fig. S7 - Distribution of Western Mediterranean subtypes of Mediterranean mixed forests.

Fig. S8 - Distribution of thermophilic subtypes of Mediterranean Mixed Forests.

Link: Sanchez_2817@supploo1.pdf 